\title{
富士山大沢扇状地の形成過程と土砂変動
}

\author{
中山政一** 今村遼平 \\ 真砂祥之助武田裕幸
}

\section{On the Process of Formation of “Osawa Fan”, Mt. Fuji and Volume Variation of Debris}

\author{
by Masaichi Nakayama, Ryohei Imamura, Syonosuke Masago \\ and Hiroyuki Takeda
}

\begin{abstract}
The debris produced at so-called "Ōsawa Rock Fall" located along the west slope of Mt. Fuji are transported through the narrow stream called "Iwa Toi" and make big deposits on "Ōsawa Fan" area. Topographic and quantitative variation of "Ösawa Fan" are discussed in this paper. Airphotogrammetric plofile survey comparing the airphotographs taken in three different stages, geologic and topographic field survey are carried out for this purpose. Results of this study are as follows;

1) This area is formed of four topographic planes, such as the original plane consisting of Fuji volcanic ejectas, the plane of old stage fan, of middle stage fan and of new stage fan. Exactly, the last plane is classified to high and low-level plane along the streams.

2) Topographically, Ōsawa fan area is classified to some sections such as the transporting section, the transporting section accompanying some deposition, the depositting section the reeroding section of fan deposits and the re-depositting section.

3) In this area the total volume variation of river bed deposits increased $195,900 \mathrm{~m}^{3}$ in volume during 4 years from 1958 to 1962 and decreased $170,600 \mathrm{~m}^{3}$ from 1962 to 1967 .

4) Debris derived from Ōsawa Rock Fall are not transported directly toward the lower area of the fan, but deposit temporarily at the upper part of the fan, then re-erosion is open from the front zone of the deposits to transport them to the lower parts to form small fan gradually. The range of deposition of fan also deviated gradually from north to south.
\end{abstract}

まえがき 富士山大沢崩れの下流部のいわゆる大沢 扇状地について, 撮影時期の異なる 3 回の空中写真を 用いて，空中横断測量による土砂変動量調査を行ない あわせて形態的変化状況を知り，当扇状地の形成機構 を明らかにしょうとした。

1）大沢扇状地には 4〜5 の地形面があるが，土砂 変動のもっとも激しいのは低位の堆積面である。

2）大沢扇状地では上流から下流にかけて，土砂の 流送区間，堆積区間，再侵食区間，再堆積区間などが 区分され，土砂は徐々に下流に移動し扇状地か形成さ れている。扇状地の分布範囲は北から南へ徐々に移動

* 大沢崩れと地質の関係については津屋弘達 $(1940,1959)$ の研究 がある。岩塚守公, 町田洋等 $(1962,1964)$ は，大沢の起源や土砂変動 量, 移動粎式などについて研究し，大沢は古大沢と現大沢とに区分され ること，その形成開始の時期は，放射性炭素による年代測定の結果で は, 古大沢は $2,500 \sim 3,000$ 年前, 現大沢はほほ 1,000 年前であるこ と, 現大沢の総侵蝕量は地形計測から $6.5 \times 10^{7} \mathrm{~m}^{3}$ と算定されること, 中下流部分の昭和 34 年以降 1 年間の土砂変動の総量は 98,000 $108,000 \mathrm{~m}^{3}$ と算定されること,などを示した。

昭和 44 年度写真測量学会にて一部講演

** 国際航業 K.K. 地質部

Kokusai Aerial Surveys Co., Ltd., Tokyo.

「写真測量」Vol. 8 No. 21969
している。

3) 昭和 33 年 10 月から 42 年 12 月までの, 土砂変 動量は差引 $25,300 \mathrm{~m}^{3}$ 増と算出されたが，33年〜37年 には差引 20 万 $\mathrm{m}^{3}$ 近い土砂が上流部より供給され, 37 年〜 42 年にはこの大半がさらに下流へ流送された ことを示している。

4）大沢扇状地での土砂供給源としては，大沢崩れ から直接供給されるものの他に, 扇状地自体の再開析 による量も大きな意味をもっている。

富士山西斜面のいわゆる「大沢崩れ」* では現在盛 んに崩壊が進んで打り，小論で対象とした昭和 33 年 10 月から同 42 年 12 月にかけては，伊勢湾台風を初 め度々の豪雨にみまわれ，かなりの土砂が生産された と推定される。生産された土砂は, 下流の大沢扇状地 に流送され，一部は堆積し一部はさらに流出したもよ うで，このため大沢扇状地内で激しい土砂変動があっ たとみられる。この土砂変動量と, その移動形態・堆 積形態を明らかにするために空中横断測量, 写真判読, 現地調查を行なった。小論ではその調査結果の一部に 


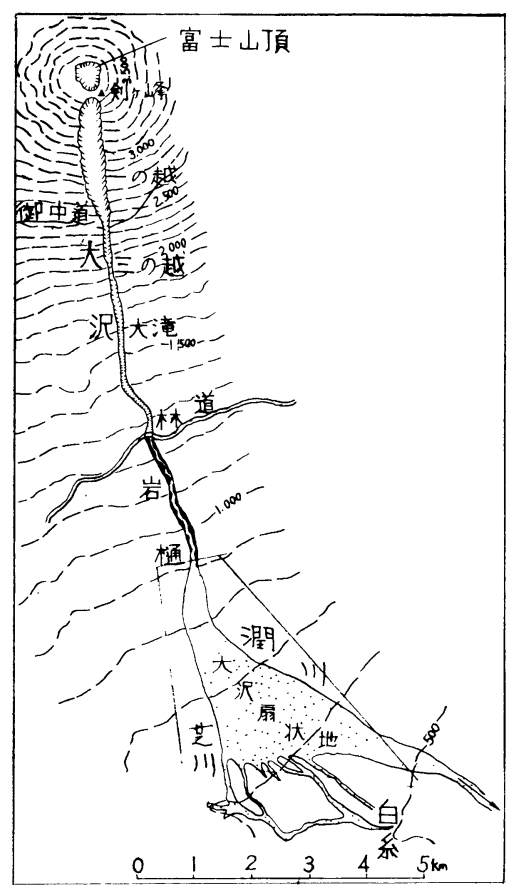

図 1 調査区域図

Fig. 1. Map showing surveyed area.

ついて述べる。

調査区域は，標高約 $900 \mathrm{~m}$ の大沢岩樋末端付近か ら潤川沿いに県施工蛇かご堰堤下流 $0.3 \mathrm{Km}$ （標高約 $580 \mathrm{~m}$ ）までと，芝川分流点から下流 $0.5 \mathrm{Km}$ までの 範囲である。

この小論をまとめるにあたり，種々便宜をはかって いただた建設省沼津工事事務所の関係各位に愿く感 謝の意を表する次第である。

\section{1. 調查の方法}

この調査の内容は,

1）撮影時期の異なる空中写真から空中横断測量に より大沢扇状地の横断面図を作成し,

2）その結果を用いて各期間毎の土砂変動量を計算 ᄂ,

3）写真判読と現地踏查によって堆積形態の特性を 知ることにある。使用した空中写真は下記の通りであ る。

$\begin{array}{ccc}\text { 撮影年月 } & \text { 撮影機関 } & \text { 写真縮尺 } \\ \text { 昭和 } 33 \text { 年 } 10 \text { 月 } & \text { 静 岡 県 } & 1 / 25,000 \\ \text { 昭和 } 37 \text { 年 } 11 \text { 月 } & \text { 林 野 宁 } & 1 / 20,000 \\ \text { 昭和 } 42 \text { 年 } 12 \text { 月 } & \text { 静 岡 県 } & 1 / 11,000\end{array}$

\section{1-1. 空中横断測量}

横断測線は潤川本流で 30 本 (No. 1 No. 20 間が 約 $100 \mathrm{~m}$ 間隔，No. 20〜No. 30 間が約 $200 \mathrm{~m}$ 間隔), 芝川筋で 5 本 (No. $31 \sim$ No. 35 間が $100 \mathrm{~m}$ 間隔) 設 定した。(図 10 参照)

測定にはステレオ・プラニグラフ C8 を使用し, 前 記 3 時期の写真上で, 同一断面線沿いに，測点間隔 $10 \mathrm{~m}$ 程度を基準として各測点の標高を求めさらに地 形変換点每に細かく測定した。測定結果を縮尺縦 $1 / 100$, 横 $1 / 100$ の「河床断面図」として表した。図 2 にその 1 例を示す。

\section{1-2. 土砂変動量の計算}

前述の空中横断測量の結果を用いて各期間の各断面 線区間毎の土砂変動量を次式により計算し, 全区間に ついて集計した。

$$
\begin{aligned}
& v_{n}=1 / 2\left(S_{n}+S_{n+1}\right) \cdot l_{n . n+1} \text { ここに } \\
& S_{n}: \quad \text { 断面線 No. } n \text { の変動断面積 } \\
& l_{n . n+1}: \text { 断面線 No. } n \text { と No. } n+1 \text { 間の距離 } \\
& v_{n}: \quad \text { この区間の土砂変動量 }
\end{aligned}
$$

これを全区間について加えれば全体の土砂変動量 $V$ は $\nabla=\sum_{n}^{k} \frac{1}{2}\left(S_{n}+S_{n+1}\right) \cdot l_{n . n+1}$ で表わされる。

\section{1-3. 空中横断測量における精度}

全工程を通しての誤差は, 写真縮尺, 測定誤差, 断 面拡大率，断面線間隔などの作業条件によってその都 度異なり, 非常に複雑である。測定誤差は写真撮影高 度の $1 / 10,000 \sim 1 / 7,000$ 位といわれている。断面線間 隔は定義の仕方で幾通りも考えられ, 土量計算には結 局もっとも影響が大きい。したがって標高測定をむや みに厳密に行なっても悞差の配分がアンバランスにな ることがあり得る。ここでは，標高は $0.1 \mathrm{~m}$ 単位，断 面線間隔は $1 \mathrm{~m}$ 単位で測定し，土砂量は $100 \mathrm{~m}^{3}$ 単位 で 4 捨 5 入して扱った。

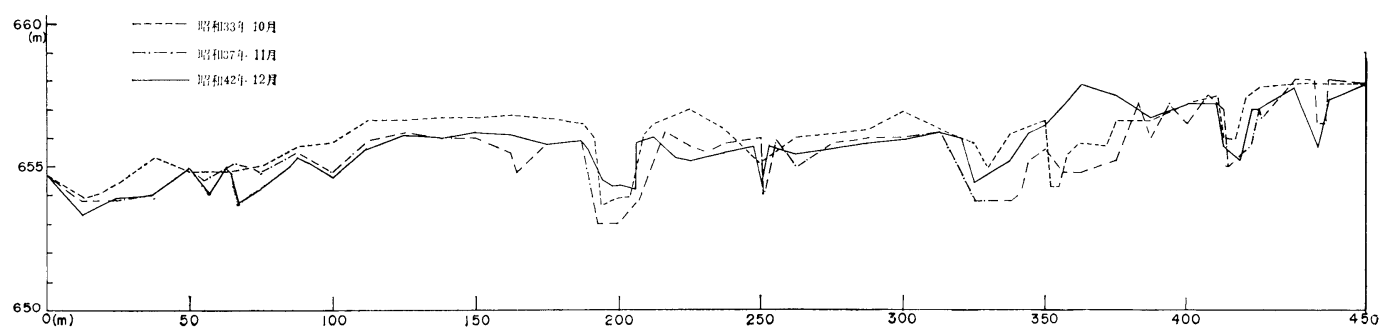

図 2 空中横断測量による河床断面図の例（断面線 No. 25）

Fig. 2. Example of river-bed profile surveyed photogrammetrically. 


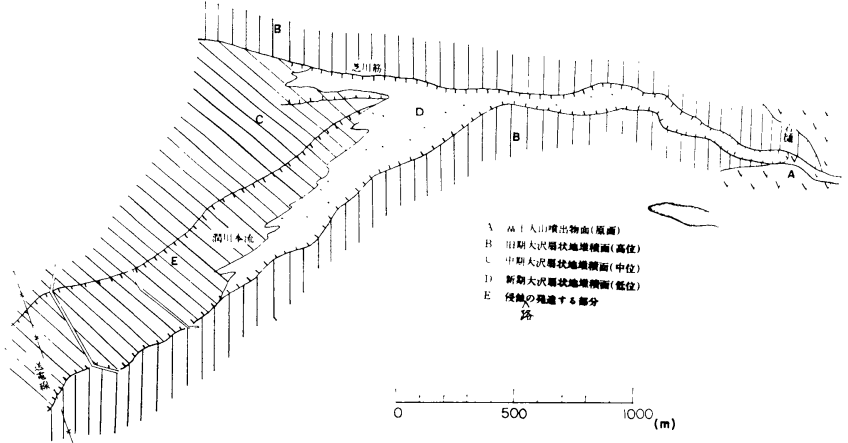

図 3 大沢扇状地の地形区分図

Fig. 3. Topographic division of surveyed area.

\section{2. 地形・地質の概要}

調查地は旧大沢扇状地に刻まれた流路と，この流路 により形成された新しい扇状地の部分にあたり，いく ぶん侵蝕されてはいるが堆積原面を示すと思われる 4 5 の地形面が最高約 $10 \mathrm{~m}$ の比高を有して分布する ところである。図 3 は調査区域を水平的に見た地形区 分図である。A 面は富士火山噴出物の凝灰角礫岩と玄

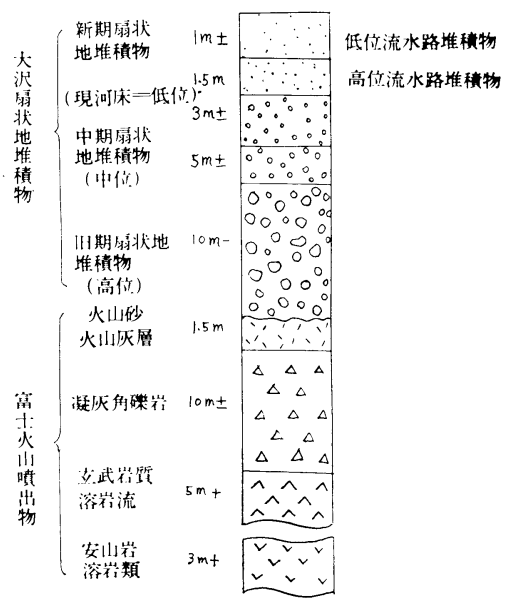

図 4 大沢扇状地々域の綜合椎状図

Fig. 4. Compiled geologic columnar section of surveyed area.
武岩質安山岩熔岩類のなす面で, 初生的 な面と考えられる。

B 面は地質時代の古い沖積扇状地堆積 物の作る面で，岩樋に近い部分では現河 床面加約 $10 \mathrm{~m}$ の比高を有する。しか し, 西方に徐々に高度を減じ, 下流の蛇 かご堰堤付近になると，これよりも新し い堆積物により形成されるC面との比高 がほとんどなくなる。また岩樋末端から 約 $500 \mathrm{~m}$ 下流付近では，A 面を構成する 上記富土火山噴出物を旧大沢扇状地堆積物が打打って いるのが観察され，さらに富士火山噴出物の上部には 暻さ約 $1.5 \mathrm{~m}$ の火山兏層加認められる。

C 面は上流から流送されてきた土砂が，流送能力の 減少によって㖊状にまき散らされてできた比較的新し い扇状地の面で, 通常, 現河床面より $3 \mathrm{~m} \pm$ の比高を 有しており，変動は比較的少ないが，4～5年間では数 $10 \mathrm{~cm}$ の変動を示す。

$\mathrm{D}$ 面は現在の河床で，土砂の移動の最もはげしい部

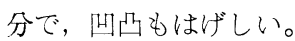

$\mathrm{E}$ 面の区域はC 面とほぼ同じものであるが, 侵蝕路 が数多く発達している点で特徴的な区域である。

調査区域の大部分を占めるのは扇状地堆積物である が, 膠結度が小さく, 脆くて, 崩れやすく, 流路の側 方侵蝕が著しく進んでいるのが見られる。

植生はD面が最も不良で, C 面, E 面は灌木, 雑草, 広葉樹など多く，A面，B面では針葉樹もかなり混じ っているのが見られるなど, 地形面と密接な関係があ る。図 4 に総合地質柱状図を示す。

\section{3. 大沢扇状地の形態的変化}

\section{3-1. 縦方向の形態的変化}

3 時期の空中写真の判読から得られた大沢扇状地の 形態的区分図から知られる事項をとりまとめて表 1 に

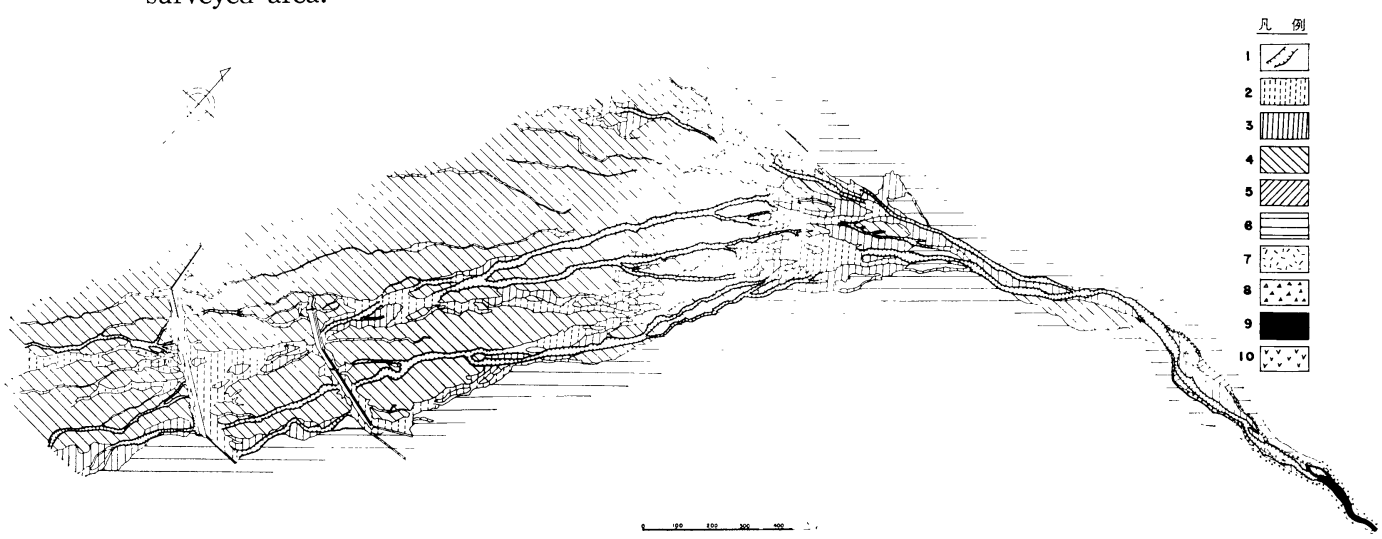

図 5 大沢扇状地の形態的区分図

Fig. 5. Morphologic division of surveyed area. 
表 1 大沢扇状地における区間ごとの特徵

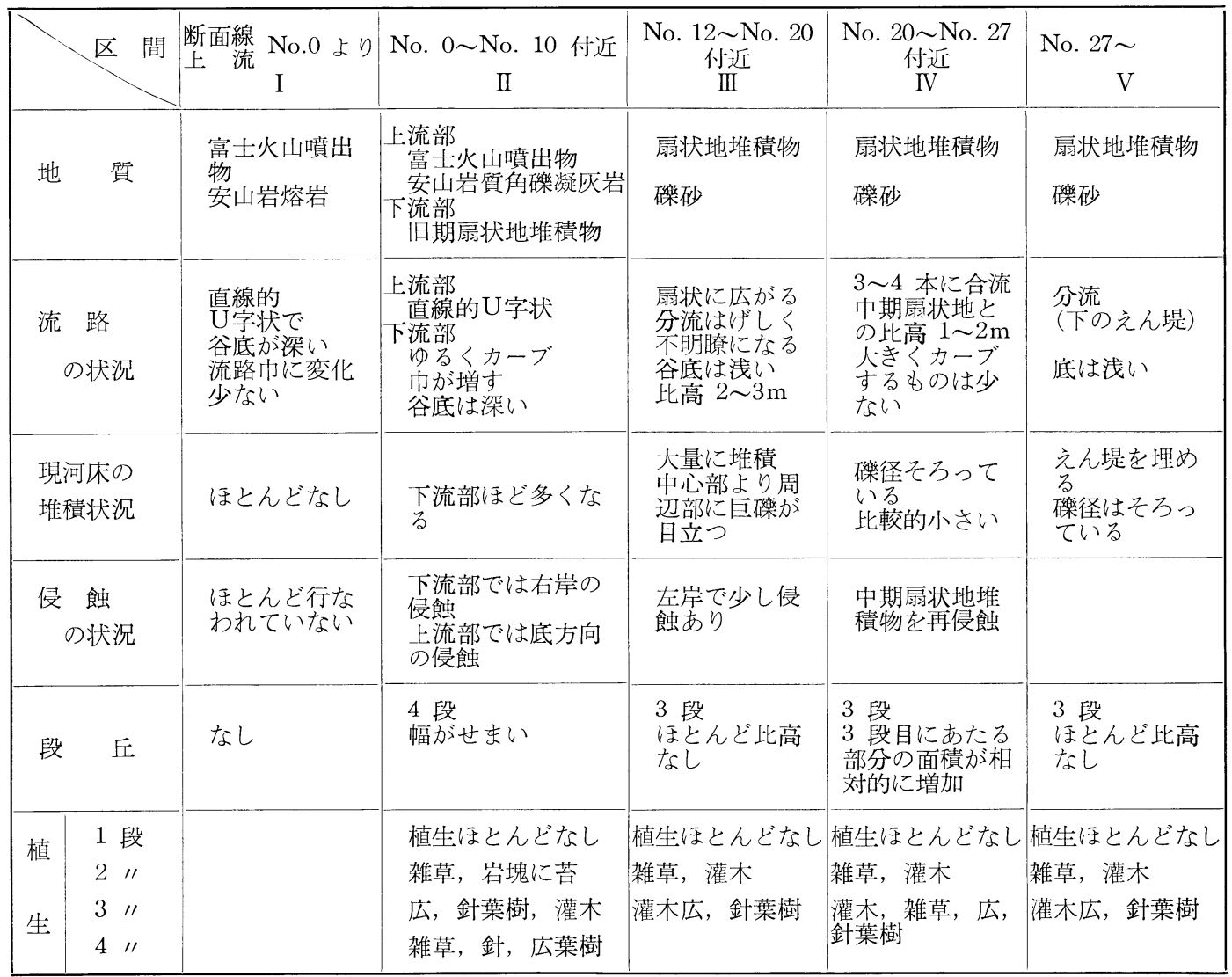

示した。

\section{図 5 の凡例}

1. 侵蝕路（堆積物）

2. 低位流水路 (堆積物) 新期扇状地堆積物

3. 高位流水路（堆積物）

4. 中期扇状地堆積物 (低位)) 中期扇状地堆積

5. 中期扇状地堆積物 (高位) 物 (中位)

6. 旧期扇状地堆積物

7. 火山砂 - 火山质層

8. 凝死角碩岩

9. 富士見橋熔岩流

10. 富士山新期熔岩流

(高位)

図 5 はその中の昭和 42 年の写真と現地踏査から作成し たものである。本地区は前述したように，主に富士火 山噴出物と扇状地堆積物からなっており, これら構成 物の膠結度, 固さなどの相異が, 河道の侵蝕などの形 態上の変化に大きく影響している。河道は, 標高的 $900 \mathrm{~m}$ 付近より上部の岩樋と称する富士火山の熔岩中 を刻んだ樋状の部分では浅くて, ほとんど側方・下方 侵蝕のない完全流送区間となっている。3 時期とも河 道の変化は全くみられない。岩樋末端からその下流約 $500 \mathrm{~m}$ にわたる，凝死角砅岩を主とした火山噴出物の
分布する区間では，河道は直線的にのび，比高約 $10 \mathrm{~m}$ の垂直の崖をもつU字形を呈している。このことは下 方侵蝕はかなり行なわれているが，側方侵蝕は弱いこ とを示している。しかし, 扇状地堆積物の分布する区 間にはいると，河道はやや低平となり，また蛇行が見 立ってきて，下方侵蝕よりむしろ側方侵蝕の方が活発 となることを示している。

傾斜変換点となる断面線 No. 15 付近から, 河道は

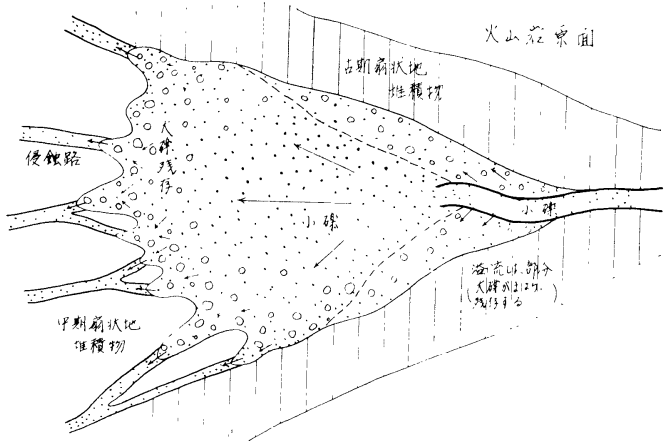

図 6 大沢扇状地の大量堆積区にお忖る堆積と再 侵蝕を示す図

Fig. 6. Schematic figure showing the relation between deposition and re-erosion at mass-deposition area. 
扇状にいくつにも分岐し，はっきり追跡出来なくなる。 運ばれて来た土砂がこの付近でまき散らされること と, 河道が消滅することは密接な関係があることは明 らかでここまで土砂を流送して来た流水が地形的変 化によって分岐伏流して流送能力を失なうためと解さ れる。まき散らされた土砂の末端は, 後述するように そのやや下流側から再び発達する分岐河道中に流れ込 んだような形で堆積しているのが特徵的である。

(図

\section{6 参照)}

さらに下流に達すると一度分散して不明瞭になった 流路とは別に，流送されてきた最も新しい土砂（扇状 地堆積物）の末端付近から新たに別個の細かい侵蝕流 路が形成され，それらの何本かが互いに合流して，周 囲と 1 2m の比高を有する河道へと発展している。 こうした現象は，小規模ながらも下流の蛇かご堰堤付 近に沶いても一部観察される。

また，断面線 No. 5 付近には高さの異なる 4 つの 面が認められるが，扇状地の部分では 3 面しか認めら れない。さらに, 前者の面は垂直に切り立った小崖で 境されているため境界が明確であるが分布が狭く，後 者は境界は不明瞭となるが分布面樻は広いという点で 対照的である。

植生は，第 1 段（現河床堆積物のうちの低位流水路 面。図 4 参照）には稀に碩に苔が付着しているくらい でほとんどない。第 2 段（高位流水路面）には，雑草 ないしは苔類の生育が観察され，第 3 段目（中期扇状 地堆積物面）には, 灌木, 雑草, 広葉樹が主に分布す る。4 段目の旧期扇状地堆積物面には広葉樹, 針葉樹, 灌木などが生育している。このように，地形面と植生 との間に密接な関係が存することが，写真判読上大き
な効果をもたらすことはいうまでもない。

現河道によって流送された最も新しい土砂（扇状地 堆積物）は，断面線 No. 15 の下流で大量に堆積し盛 り上っているのが明確に判読できる。現地踏査による と，礫径は一般に下流になるほど小さくなるようであ る。さらに，大量堆積区の中心部付近で粒径が細かく なる傾向がある。ところが，大量堆積区の末端，すな わち新たに小さな侵蝕流路が形成される部分では，大 礫がゴロゴロしているのが目立つ（図 6)。

以上述べてきた事柄をまとめると次のようになる。 (1)現在のところ, とくに侵蝕, 流送, 堆積など土砂変 動に直接関係するのは, 主として現河床堆積物であ る低・高両流水路の 2 面であり，3 段目の中期扇状 地堆積物の面にまで影響を及ぼすことは少ない。

(2)流送を主とした地域に打ける河道は，U字形を呈し て底が深く，河道幅の変化もなく直線的であるのに 対し，側方侵蝕の著しい地域打よび土砂の堆積を主 とした地域では，幅が広く底の浅いのがめだち，河 道の変化もはげしい。

(3)扇状地は一般に流路変化のはげしいのが常である が，とくに堆積区でその傾向がつよく，断面線No.

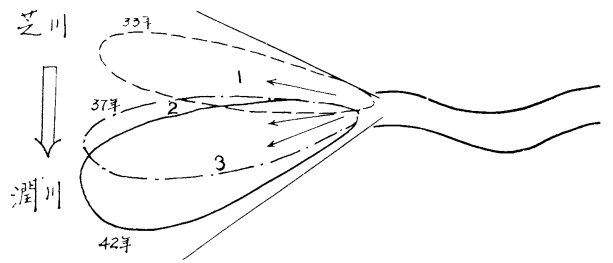

図 7 大量堆積区の時間的変遷を示す図

Fig. 7. Schematic figure showing the periodical deviation of mass-deposition area.

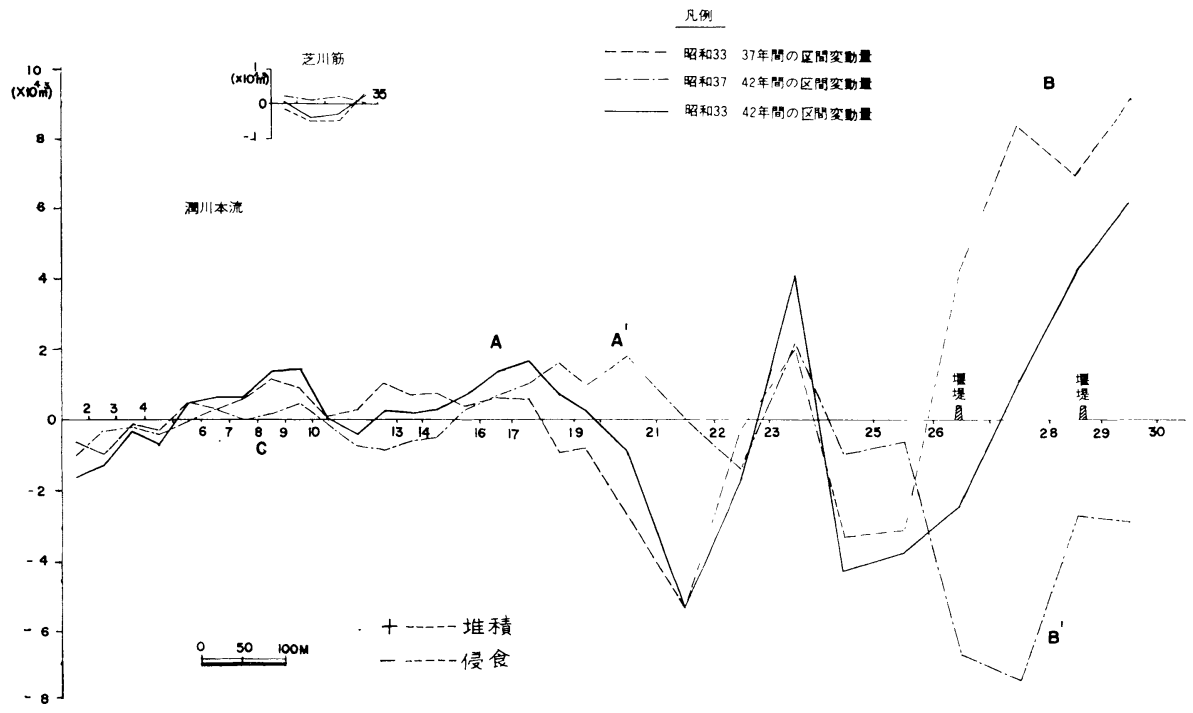

図 8 大沢扇状地に抢ける区間河床変動量

Fig. 8. Figure showing volume variation of riverbed deposits at surveyed area. 
15より下流のような大量堆積区では流路そのものが 不明瞭になり，ついには消滅してしまう。

(4)侵蝕区間や堆積区間は常に同一場所に定まっている のではなく，時間的経過に従って多少移動する。

\section{3-2. 横方向の形態的変化}

上述のような河道に沿った縦方向に打ける形態的変 化とは別に，大量堆積区間では時間的経過とともに横 方向への堆積区の変遷が認められる（図 7)

すなわち，昭和 33 年の空中写真にみられる断面線 No. 13〜14 付近では, 河道は芝川筋に向いており主 としてこの方向に流水とともに土砂をはき出して来た ことがうかがわれる。ところが昭和 37 年の写真では 断面線 No. 10 付近で南側に分流が始まり，流路の幅 自体は広くはないが，この方向が地形的にみて低地と なっているため, 多量の土砂と水をこの方向にもたら したと推測される。さらに昭和 42 年になると流路の 主体は現在みるごとく完全に南側のものとなり，芝川 筋に向いていたものは流路幅も狭くなり，明確に流路 と認められる部分も不連続になっている。このこと は，再侵蝕区間である断面線 No. 20〜27 付近にも反 映されており，昭和 33 年には潤川左岸に沿って明膫 な流路が認められなかったにもかかわらず，昭和 42 年 のものには左岸沿いに明瞭に流路が認められるように 変っている。また，堆積物も芝川筋に厚く堆積してお り，断面線 No. 13 付近で芝川筋と本流側とでは， $3 \mathrm{~m}$ 近くの比高がある。これらの事柄は,かつては芝川筋方 向に土砂が運搬堆積されていたのが，この付近が大量 堆積区間となったため, 隣接する相対的な低地であっ
た南側にその方向を変えたものと見ることができる。

このように, 大沢尿状地では, 断面線 No. 12 付近 を要として土砂堆積区が，北から南に向けて移動して おり，(図 7)，この傾向は今後も進むものと思われる。 しかし, ある程度南側で堆積が進行すると周囲より地 形的に高くなるため，再び，北側に向けて堆積区が移 動するものと思われる。このような移動が何年位の周 期を有するか，現在のところまだ明らかでない。

\section{4. 大沢扇状地堆積物の量的変化}

表 2 に岩樋から蛇かご堰堤に至る区間の土砂変動量 を示す。

表 2 大沢扇状地における土砂変動量 単位 $\mathrm{m}^{3}$

\begin{tabular}{|c|c|c|c|}
\hline & $\begin{array}{c}\text { 昭 } 33 \text { 年 } \\
\text { 昭 } 37 \text { 年 }\end{array}$ & $\begin{array}{c}\text { 昭 } 37 \text { 年 } \\
\text { 昭 } 42 \text { 年 }\end{array}$ & $\begin{array}{c}\text { 昭 } 33 \text { 年 } \\
\text { 昭 } 42 \text { 年 }\end{array}$ \\
\hline 潤川本川 & 204,200 & $-175,600$ & 28,600 \\
\hline 芝川筋 & $-8,300$ & 5,000 & $-3,300$ \\
\hline 計 & 195,900 & -170.600 & 25,300 \\
\hline
\end{tabular}

また図 8 及び図 9 には各断面区間每の区間土砂変動量 と累加土砂変動量を示す。

これらの表, 及び図から判る通り, 昭和 33 年 10 月 から昭和 37 年 11 月までの 4 年前に，潤川本流で $204,200 \mathrm{~m}^{3}$ の土砂量の増加があり, 芝川筋で $8,300 \mathrm{~m}^{3}$ の減少を示している。使用した最初の写真が昭和 33 年 10月に撮影されたものであることから，この 20 万 $\mathrm{m}^{3}$ に近い量の土砂をもたらした最大の原因は，昭和34年 9 月の伊勢湾台風, 昭和 36 年 6 月の梅雨前線豪雨及

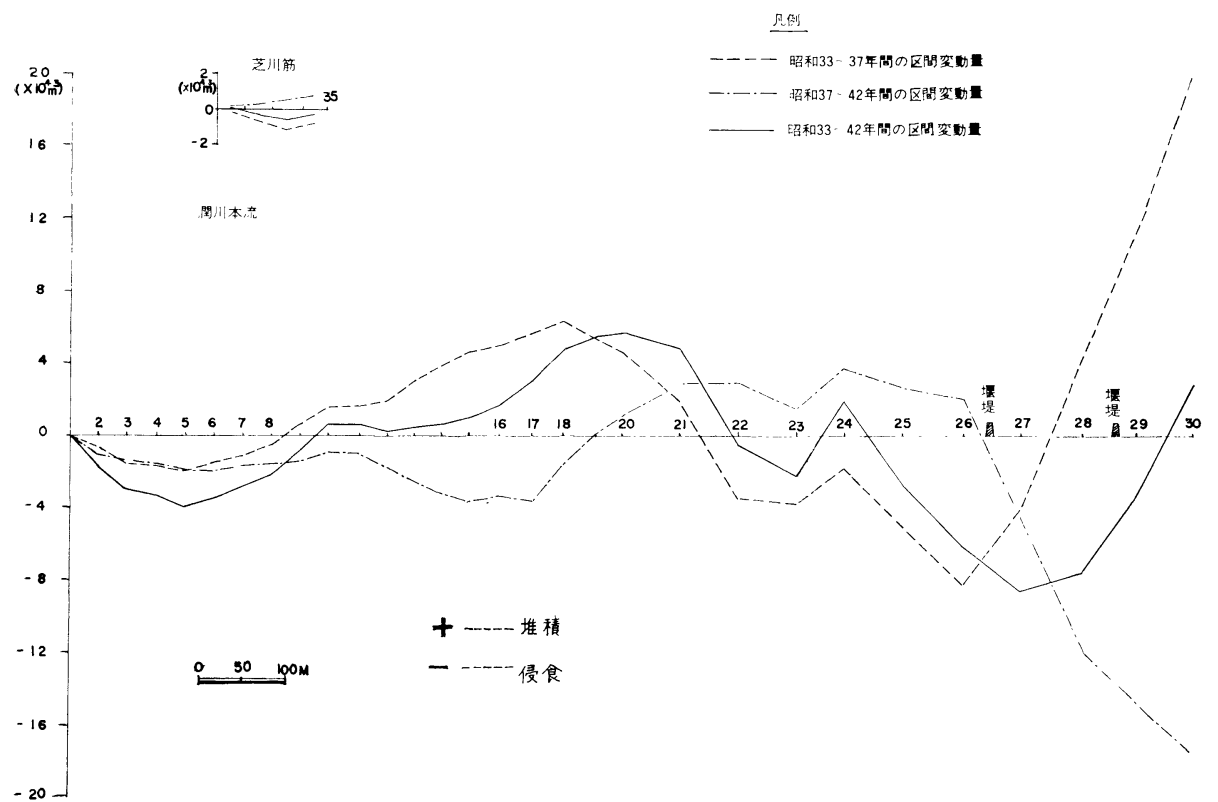

図 9 大沢扇状地における累加河床変動量

Fig. 9. Figure showing accumulated volume variation of river bed deposits at surveyed area. 


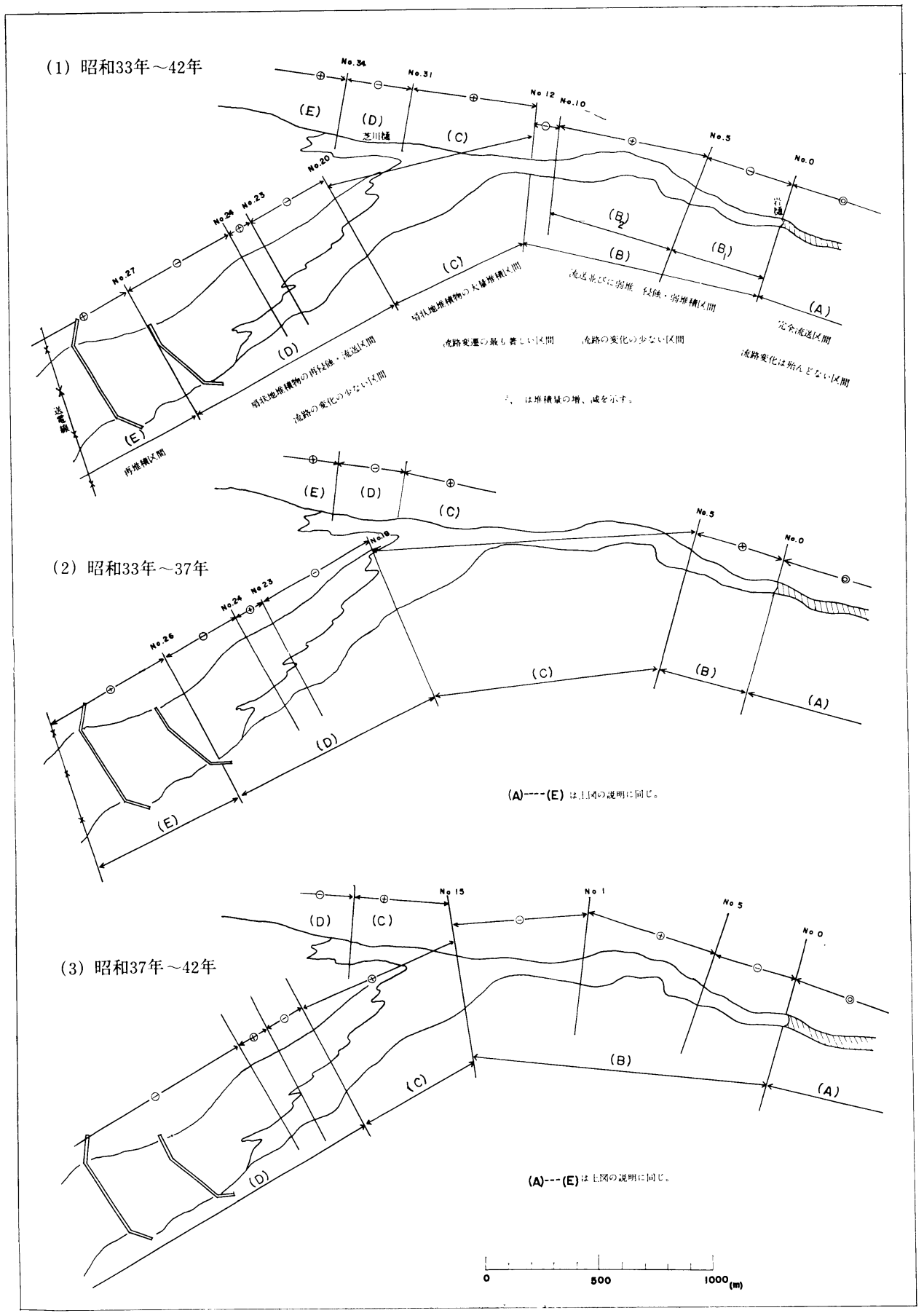

図 10 大沢扇状地における侵蝕, 流送, 堆積の区分図

Fig. 10. Diuision of erosion transportation and deposion at surveyed area.

び，同年 9 月の第二室戸台風などに伴う集中豪雨であ ろろと考えられる。

一方，昭和 37 年 11 月から昭和 42 年 12 月までの 5 月間では, 潤川本流においては $175,600 \mathrm{~m}^{3}$ の減少, 芝川筋で $5,000 \mathrm{~m}^{3}$ の増加, 差引き， $170,6000 \mathrm{~m}^{3}$ の 減少という值を示して抢り，この期間は減少する一方
だったと見ることも出来る。この間には，昭和 41 年 9 月の台風 26 号, 42 年 8 月の羽越災害をもたらした豪 雨などがあり，その際にこの地域でもかなりの豪雨が あった筈であるが，それにも拘らず減少している理由 としては次の様に解釈される。

図 8 に执いて，A で示された地域の堆積物は $\mathrm{A}^{\prime} に$ 
移動しており, Bで示された地域の堆積物が，昭和 37 〜 42 年間に大量に侵蝕されたため $\mathrm{B}^{\prime}$ の部分が減少の 区間として表現されたとある事が出来る。一方，Cで 示されるように断面線 No. 5〜10 付近に多少の堆積を みているが，その量は酸に打ける減少の量と比較する とはるかに小さい。つまり，大沢崩れからの土砂供給 もかなりあったのであるが, それよりも, 既に堆積して いた扇状地堆積物の再侵蝕量の方が，はるかに大きか ったと見ることが出来る。

昭和 37〜42 年間に, 本地域下流部に 2 基の蛇かご えん堤が建設されている。現地で見ると，上流部のえ ん堤はまだ満砂になっていないが，下部のえん堤はほ ぼ満砂状態になっている。それにも拘らず，河床変動 曲線としては，この影響は殆んど表現されていない。 これは恐らく，(1)えん堤による堆砂が極く限られた範 囲で，断面線 No. 28 にも殆んど達しない程度である こと，(2)えん堤による堆砂の影響をはるかにしのぐ量 の扇状地堆積物の再侵蝕が， えん堤建設以前に行われ たことなどによるものと考えられる。（図 10）

\section{5. 大沢扇状地の形成機構}

大沢扇状地の形態的変化と量的変化から, 当扇状地 の形成機構は次のごとく考えられる。

河道がはっきり定まっている流送区間を流送されて

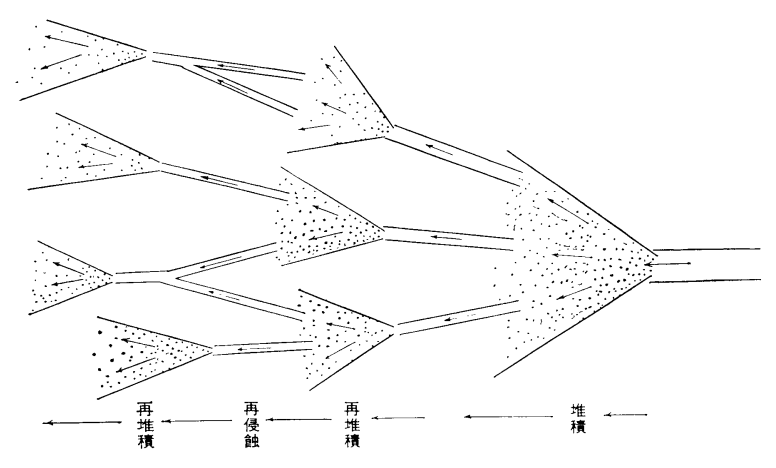

図 11 大沢扇状地の形成機構

Fig. 11. Process of formation of Osawa Fan.

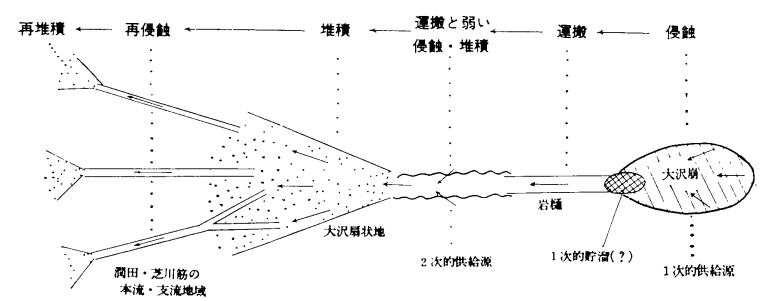

図 12 大沢に掞ける侵蝕, 流送, 堆積の過程を示す 模式図

Fig. 12. Schematic figure showing the process of erosion, transportation and deposion at Osawa Fan.
きた土砂は, 扇状地の要の部分（No. 13 付近）に達 すると流水と共に古い扇状地堆積物上にまき散らされ る。これは流路が定まっていないこと, 傾斜変換点で あることの他に直接的には，この付近から流水が伏流 したり分流したりするため流送能力を失うためであ る。それは下位の扇状地堆積物が空隙に富むことと, 地形的に扇状地の中央部分, すなわち要の部分と弧の 中央付近を結んだ線沿いの部分，が相対的にややふく れた楯状を呈していることによる。図 11 の模式図に 示すように, 要の部分付近よりまき散らされた土砂は, そこから一気に下流へ流送されることは少なく，その 大部分は末端を，それ以前に形成された流水路中につ つ込んだ形で堆積している。

ところが, 時間の経過に従って, 堆積した土砂の末 端部付近から次第に水系が形成され再侵蝕が徐々に堆 積土砂の内側へと進展してくる。この場合の侵蝕は流 域面積や流水量の関係で急激に行なわれるものではな いため, 粒径の大きな礫を下流へ運搬するだけの力は なく, 大礫岩を理めている小礫を主とした土砂を運搬 する程度にとどまるようである。大量堆積区間の末端 部付近に大礫が見立つのは, 上述のようにして大礫間 を充填する小碩が流失したためであろうと考えられ る。(図 6)

大量堆積間の末端から新たに形成された流水路は, 次第にはっきりした流路を有する流水路に発展 し, 再びこれらの流水路による流送。堆積が行 なわれる。すなわち，大沢扇状地を縦方向にみ た場合は, 図 12 の模式図に示すように, 堆積 $\rightarrow$ 再侵蝕 $\rightarrow$ 再堆積という過程をくり返しつつ土 砂は次第に下方へ流送され扇状地が形成されて 行 $<$ 。

大沢扇状地を横方向についてみた場合, 大量 堆積区では土砂は扇形に広く万遍なくまき散ら されるのではなく, 図7に示したように, 堆積 区はむしろ比較的せまい範囲に限られ，それが 時間的変化と共に移動する。昭和 33 年から 42 年の間に土砂大量堆積区は北加ら南へ移ってい ることがわかる。土砂の堆積が進むにつれ堆積 部分が次第に高くなるため, 流水は流れ易い低 位部を選んで流れるようになり，自然に堆積区 は移動するわけであろう。

以上述べたように，大沢扇状地は縦方向にも 横方向にもある一つのサイクルを有しながら形 成されて来ているといえよう。

\section{6. 大沢扇状地における土砕供給機構}


土砂変動量の測定結果と現地における踏查の結果か ら, 大沢扇状地に打ける土砂供給の機構は次の様に考 えられる。

大沢扇状地へ
の土砂供給

a）増水時の削剝による供給

b）日常的削剝，崩落によって蓄積 された崖錐状堆積物からの供給

1) は，大沢扇状地上流の大沢崩れで崩壊した崩壊 物が，豪雨時に一気に下流まで押し出されるものをい い，土砂供給の仕方としては直接的（一次的）なもの である。もちろん，供給源となる上流の大沢崩れでは 四季を通じて行われる削剥, 崩落（岩塚ほか: 1964） によって蓄積された土砂が豪雨時の流水によって押し 出される場合や，大沢崩れ地域が流水によって直接え ぐり取られて下に押し出される場合などがあろうが， いづれにしろ大沢扇状地から見た場合には，1）は大 沢から直接大沢扇状地へ押し出されて来るような供給 機構をいうものである。まだこの場合にも，大沢崩れ から供給された土砂が一時的に貯溜されるような場所 が岩樋より上流の地域にある事が充分考えられるが (図 12) その点についてはまだ今後の研究に待たねば ならない。

2 ）は，過去において大沢崩れから供給された土砂 が，大沢扇状地堆積物として厚く堆積し，それが現在 再び侵蝕されるものをいう。

扇状地堆積物からの土砂供給も場所的に見ると, 岩 樋終点から扇状地のいわゆる要の部分までの, 旧期扇 状地堆積物（凝灭角礫岩も類似しているのでこれに含 めて考える) の側方侵蝕地域（図10（B）地域）及び それより更に下流の再侵蝕地域（図 $10(\mathrm{C})$ 地域) 及び それより更に下流の再侵蝕地域（図 $10(\mathrm{D})$ 地域) など がこの供給機構に相当する。いづれも扇状地堆積物の 再侵蝕によって供給されるという点で共通している。

しかしながら, 同じ扇状地堆積物から供給される場 合にも，(a）豪雨による增水時に流水によって河道の 側面または底面が削り取られる場合と，(b) 四季を通 じて日常的に行れる扇状地堆積物の削剝・崩落によっ て形成された崖錐状の蓄積土砂が, 增水時の流水によ って運ばれる場合の 2 通りが考えられる。

図 5 に侵蝕路として示した部分は，增水時の流水に よって特に激しく侵蝕を受ける部分である。その他の 部分子，（1）新期大沢扇状地堆積物，(2) 中期大沢扇 状地堆積物，（3）旧期大沢扇状地堆積物，（4）凝灰角 磎岩の順に侵蝕され易くなる。

大沢扇状地堆積物は新旧の違いによって分布高度に 差はあるが，いづれも非常にルーズであるため, 四季
を通じて砂碩の削剝・崩落は続いている。こうして崩 落した土砂は河床堆積物上に崖錐として貯溜されてい る。(図 13)

これらの崖錐はちょっとした流水にも脚部を洗掘 されると容易に流出するもので，大沢扇状地における 土砂流出に大きなウェイトを占めるものである。

以上のように, 大沢扇状地に打ける土砂供給には大 きくみて $2 つ の$ 機構が考えられるが，小論に抢いては その量比を定量的に求めるまでには至っていない。し かし, 河床変動量の計測結果と, 昭和 33 年〜 42 年間 の災害史, 及び現地踏查の結果等を総合すると, 台風 や集中豪雨など雨量強度の大きな場合には, 大沢崩れ, からの直接的供給が大きなウェイトを占め, 単なる豪 雨程度では, 大沢扇状地からの供給の方が大きなウェ イトを占めるものと推測される。

あとがき 大沢扇状地は富士山西斜面に刻まれた大 沢崩れから流送された土砂が一時的に堆積する場所に あたる。昭和 33 年, 37 年および 42 年の 3 時期に撮影 された空中写真から当地区の空中横断測量を行ない, これに現地踏查と写真判読を併せて大沢扇状地におけ る時間的空間的にみた形態変化と量的変化を求め, こ れらから大沢扇状地の形成機構, 土砂供給機構を明ら 功しようとした。

今後, 大沢扇状地より上流域に打ける土砂変動量を 追うことにより, 大沢䨒状地全体の土砂量の収支を求 めることが出来よう。またいわゆる大沢崩れから供給 される土砂量と扇状地堆積物の侵蝕によって供給され る量との比を求めることも出来よう。これらの点は今 後の砂防刘策上基本的なことであり今後追求すべき課 題である。

\section{参考文献}

1. 津屋弘迬: 富士火山の地質学的並に岩石学的研究 地学雑誌 Vol. 52 No. 6181940

2. 同 : 大沢沿岸地域の地質と大沢崩れの発達 静岡県 1959

3. 同：富士火山地質図 地質調查所 1968

4. 岩塚守公・町田 洋: 富士山大沢の発達 地学雑誌 Vol. 71 No. 4

5. 岩塚守公・町田 洋・小池一之：

富士山大沢に見られる砂碩移動の特性 水利科学 No. 361964

6. 建設省沼津工事及務所・国際航業 K.K.

昭 43 年度富士山大沢扇状地河床変動 調查 1969 